
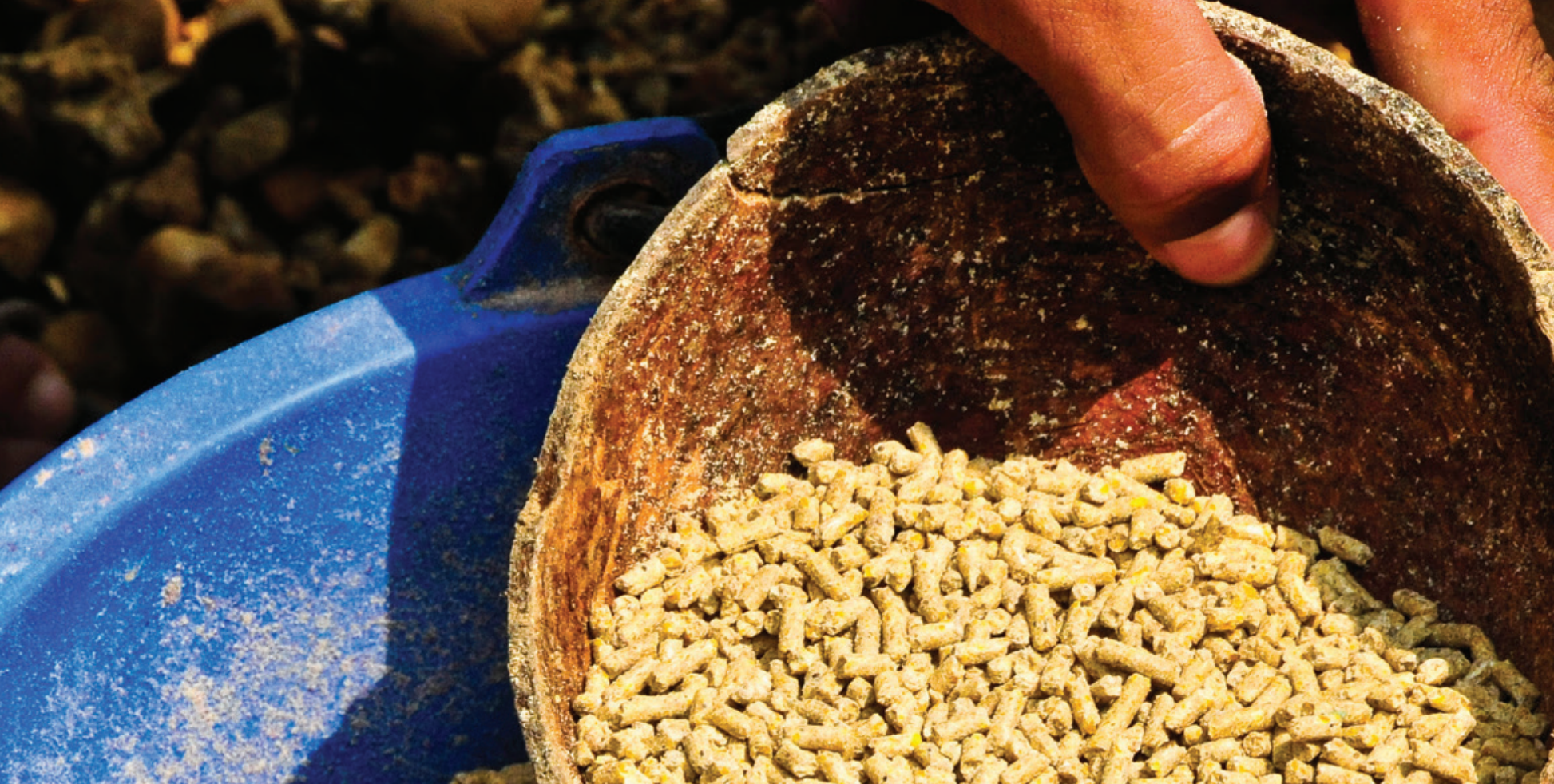

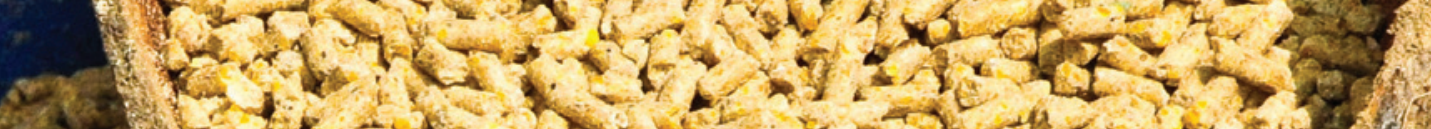

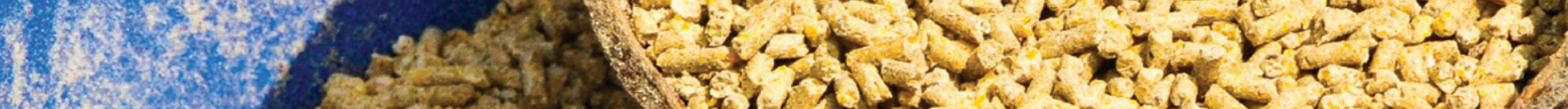

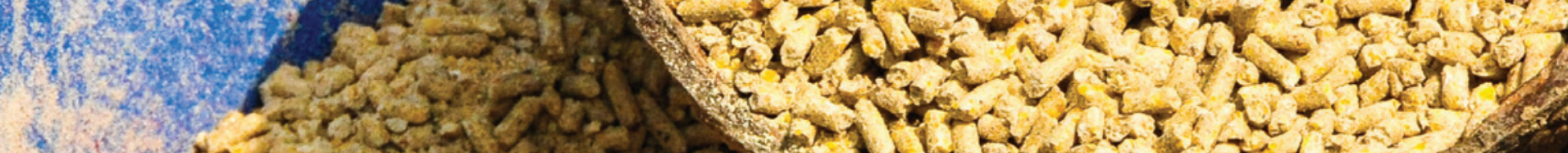

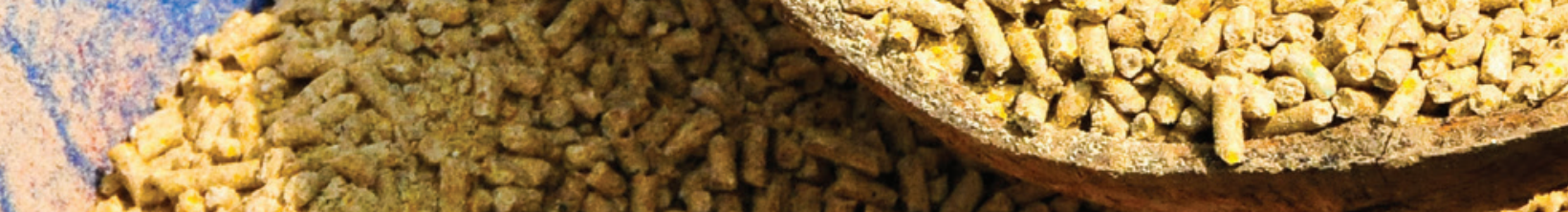

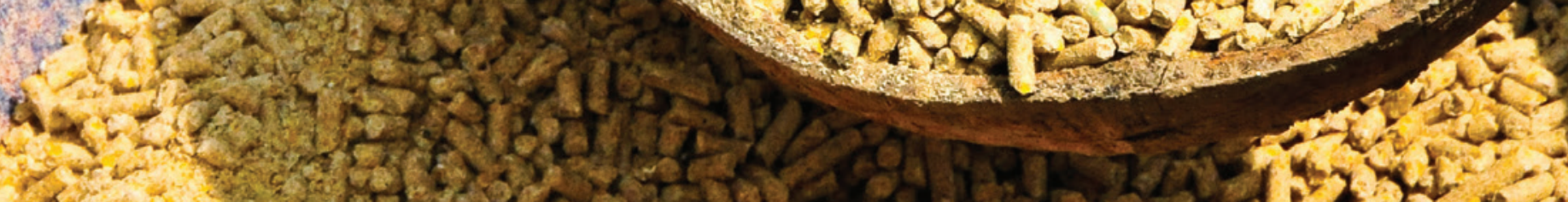

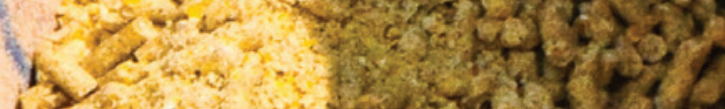

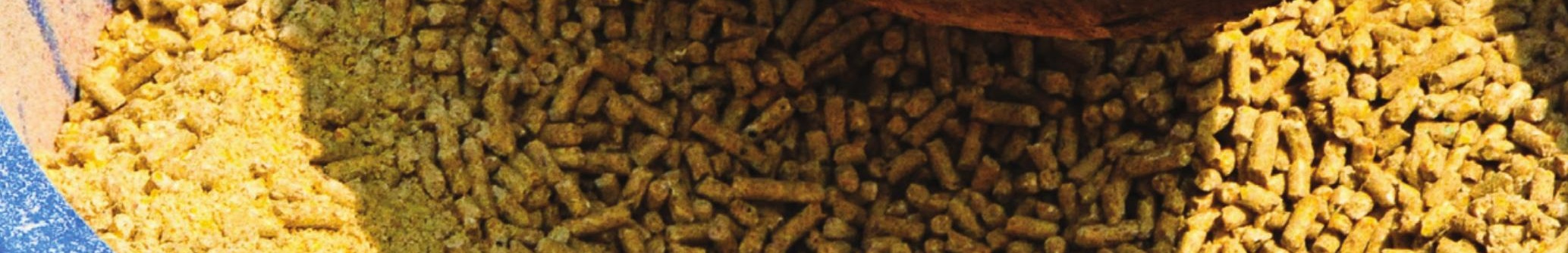

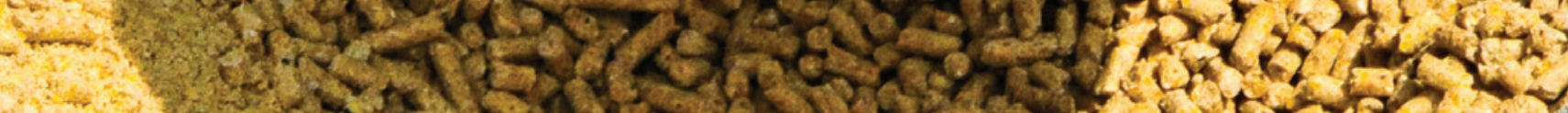
5.12 w.

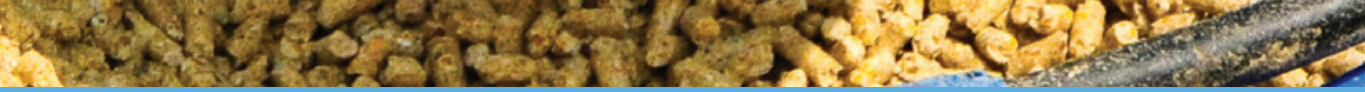

IAG ring test feed composition 2016 



\section{IAG ring test feed composition 2016}

L.W.D. van Raamsdonk, N. van de Rhee, V.G.Z. Pinckaers, J.J.M. Vliege 
Raamsdonk, L.W.D. van, N. van de Rhee, V. Pinckaers, J.J.M. Vliege, 2016. IAG ring test feed composition 2016. Wageningen, RIKILT Wageningen University \& Research, RIKILT report 2016.014. 24 pp.; 2 fig.; 2 tab.; 10 ref.

Project number: 126.73 .351 .01

Project title: IAG ringtesten

Project leader: L.W.D. van Raamsdonk

This report can be downloaded for free at http://dx.doi.org/10.18174/393610 or at www.wur.eu/rikilt (under RIKILT publications).

(C) 2016 RIKILT Wageningen University \& Research

The client is allowed to publish or distribute the full report to third parties. Without prior written permission from RIKILT it is not allowed to:

a) publish parts of this report;

b) use this report or title of this report in conducting legal procedures, for advertising, acquisition or other commercial purposes;

c) use the name of RIKILT other than as author of this report.

P.O. Box 230, 6700 AA Wageningen, The Netherlands, T +31 (0)317 4802 56, E info.RIKILT@wur.nl, www.wur.eu/rikilt. RIKILT is part of Wageningen University \& Research.

This report from RIKILT has been produced with the utmost care. However, RIKILT does not accept liability for any claims based on the contents of this report.

RIKILT report 2016.014

Distribution list:

- International Association for Feeding stuff Analysis (IAG), Section Feeding stuff Microscopy (I. Paradies-Severin, J. Vancutsem, G. Frick, R. Weiss)

- European Union Reference Laboratory, Animal Proteins (CRA-W; G. Berben, P. Veys, V. Baeten)

- Joint Research Centre, Geel (IRMM-JRC; C. von Holst, A. Boix-Sanfeliu)

- All participants of the ring test

- Competent authorities of EU member states 


\section{Contents}

$\begin{array}{ll}\text { Summary } & 5\end{array}$

$\begin{array}{lll}1 & \text { Introduction } & 7\end{array}$

$\begin{array}{llr}2 & \text { Methods } & 8\end{array}$

2.1 Materials and procedure $\quad 8$

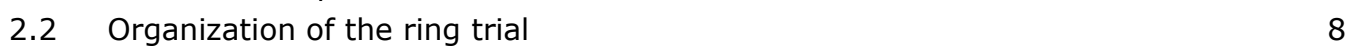

$\begin{array}{lll}2.3 & \text { Analysis of results } & 8\end{array}$

$\begin{array}{lrr}3 & \text { Results } & 10\end{array}$

4 Discussion $\quad 12$

4.1 Method application $\quad 12$

4.2 Justification for establishing composition 12

$\begin{array}{llr}5 & \text { General conclusions and recommendations } & 14\end{array}$

$\begin{array}{lll}5.1 & \text { Conclusions } & 14\end{array}$

5.2 Recommendations $\quad 14$

$\begin{array}{ll}\text { Acknowledgements } & 15\end{array}$

$\begin{array}{ll}\text { References } & 16\end{array}$

$\begin{array}{lll}\text { Annex } 1 & \text { Basic instructions for the test procedure } & 17\end{array}$

$\begin{array}{lll}\text { Annex } 2 & \text { Report form for procedure details } & 18\end{array}$

$\begin{array}{llr}\text { Annex } 3 & \text { Report form results } & 19\end{array}$

$\begin{array}{lll}\text { Annex } 4 & \text { Additional instructions } & \mathbf{2 0}\end{array}$

$\begin{array}{lll}\text { Annex } 5 & \text { List of participants } & 21\end{array}$

$\begin{array}{lll}\text { Annex } 6 & \text { Results } & 22\end{array}$ 



\section{Summary}

The analysis of composition in terms of ingredients is important for detecting economic fraud and for monitoring feed safety. Composition analysis and label control of feed is regulated in Regulation (EC) 767/2009. In a broader view, composition analysis in the entire food chain can improve the effect of monitoring actions. The new legislation on food labelling (Regulation (EC) 1169/2011), effective from December $13^{\text {th }} 2014$, obliges to provide more detailed information to customers on composition and related topics.

A ring test was organized for the microscopic determination of botanic composition in animal feed in the framework of the annual ring tests of the IAG - International Association for Feeding stuff Analysis, Section Feeding stuff Microscopy. The organizer of the ring test was RIKILT - Wageningen UR, The Netherlands. The aim of the ring study was to provide the participants information on the performance of the local implementation of the method for composition analysis of feed.

The sample was based on an artificially produced feed mimicking a ruminant feed, and distributed without label information. The participants were requested to produce a correct declaration of the ingredients of the sample. The results were analysed using the IAG model for uncertainty limits. Shares of ingredients in the feed formulation outside the limits of the model were indicated as underor over-estimations.

A total of 25 sets of results was returned. The percentage of under- or over-estimations was $28.6 \%$ for the seven main ingredients. In the overview of results, the two declared wheat ingredients and the two declared corn products were pooled to one ingredient each. This was necessary since some participants declared a general ingredient ("wheat" and "corn") and others a specific type (gluten or bran). The use of the original declarations would result in an extra number of non-matching estimations without precise justification. The share of the citrus pulp, in the presence of an equal amount of beet pulp, was underestimated or not detected in $44 \%$ of the results. Citrus pulp as such is recognisable as feed ingredient. Still almost three quarter of all estimations appeared to be correct in the ranges of the uncertainty model. This means that visual inspection of the composition of a sample can be used for label control and this method can support traceability of ingredients in case of an incidence.

The current results indicate that specific formulations can influence the precision of the estimation of the composition of the feed. The current lack of a complementary system for (chemical) proximate analysis could be a drawback for the overall approach of supporting traceability, necessary for fighting food fraud and for supporting feed safety. Besides a proper method description and up-to-date descriptions of ingredients, well developed skills of technicians are vital for a good performance. 


\section{Introduction}

In the framework of transparency and the demand for traceability of the source of feed ingredients, it is necessary to establish the formulation of a feed. The legal basis for this examination is the obligatory label declaration of feeds, regulated for years by EU legislation and currently part of Regulation (EC) 767/2009. The main objectives are the prevention of economic fraud and a sufficient monitoring of feed safety.

The analysis of composition of feeds by means of microscopic methods has a long history. It has been a major activity of the IAG section Microscopy from its existence in 1959 (www.iag-micro.org). In 1998 a protocol on the microscopic identification of ingredients in feed was established in German, and translations to English and French were decided to be prepared (http://www.iag-

micro.org/files/39_wien98.pdf?10,12).

The method IAG-A2 is based on a procedure of sieving the sample and applying several embedding and staining methods. The different sieve fractions consist of a fine, mediate and coarse material. The presence of specific ingredients (e.g. starch, fibres seed hulls) deviates largely among the sieve fractions. Examinations are to be carried out both a binocular microscope (up to $70 \times$ magnification) and a compound microscope (100 - 400 x magnification; IAG, s.n.). At the final stages the share of the different ingredients are summed up over the different sieve fractions. The methods relies on identification of the ingredients supported by handbooks or reference material (IAG, s.n.). The identification of legal ingredients (Feed catalogue: Regulation (EC) 242/2010) is a complicated procedure.

Besides the availability of a protocol, the current practices are heavily based on the existing skills of the technicians. In the view of a process of improvement of monitoring programs, which was recently established for food in Regulation (EC) 1169/2011, the maintenance and dissemination of these skills needs attention.

In this report the ring test for composition 2016 is presented, which was organised by RIKILT on behalf of the IAG Section Feeding Stuff Microscopy. 


\section{Methods}

\subsection{Materials and procedure}

The IAG ring test for botanic composition 2016 was chosen to be based on an artificial compound feed; the formulation was taken from a ruminant feed. The feed was based on a formulation with cornglutenfeed $(30 \%)$, citruspulp (15\%), beetpulp (15\%), palmkernelmeal $(15 \%)$, rapeseedmeal $(8.5 \%)$, wheat $(5 \%)$, wheat semolina $(5 \%)$, soybeanmeal $(5 \%)$ and mineral mix $(1.4 \%)$. The IAG ring test for botanic composition 2016 was combined with the IAG ring test for animal proteins (sample 2016-A). The results of this ring test are being published in a separate report (van Raamsdonk et al., 2016). More details on the initial test results are published in that report.

\subsection{Organization of the ring trial}

All IAG members, all NRLs, participants of former ring tests and a series of putative interesting laboratories were informed about the ring test for 2016. In all cases an invitation letter included in the IAG Newsletter 2015 and a participation form were distributed. Until the beginning of March a total of 27 participants for the microscopic composition analysis were listed. The samples with an accompanying letter were sent to all participants on Monday $7^{\text {th }}$ of March 2016. On Monday March $9^{\text {th }}$ an E-mail message was sent to all participants, together with a file containing a sheet with instructions (see Annex 1) and the electronic report forms (see Annex 2 and 3), and the request to confirm the receipt of the package.

The sample was intended to be analysed according to IAG method 2: "Method for the Identification and Estimation of Constituents in Animal Feedingstuff" (IAG, s.n.). Further instructions to the participants were enclosed in the box with samples, which are reproduced in Annex 4.

The closing date for reporting results was fixed at April $8^{\text {th }}$. Several requests were received to extend the period for analysis with two weeks. This request was granted and the closing date was set at April $15^{\text {th }}$. Since the analysis of the results was carried out during May, all the results were considered valid and taken into consideration.

The draft report was finalised at May $27^{\text {th }}$.

\subsection{Analysis of results}

The results are analysed according to the IAG scheme of uncertainty limits as approved during the 2006 meeting in Rostock. These limits are presented in Table 1. The model is graphically presented in Figure 1. Shares of ingredients in the feed formulation outside the limits of the model were indicated as "wrong".

Table 1 IAG model for uncertainty analysis of the composition of a compound feed.

\begin{tabular}{ll} 
Actual amount in $\%$ & Accepted uncertainty limits \\
$<2 \%$ & "traces " \\
\hline $2.0-5.0 \%$ & $+/-100 \%$ relative \\
\hline $5.01-10.0 \%$ & $+/-5 \%$ absolute \\
\hline $10.01-20.0 \%$ & $+/-50 \%$ relative \\
\hline $20.01-50.0 \%$ & $+/-10 \%$ absolute \\
\hline$>50 \%$ & $+/-20 \%$ relative \\
\hline
\end{tabular}




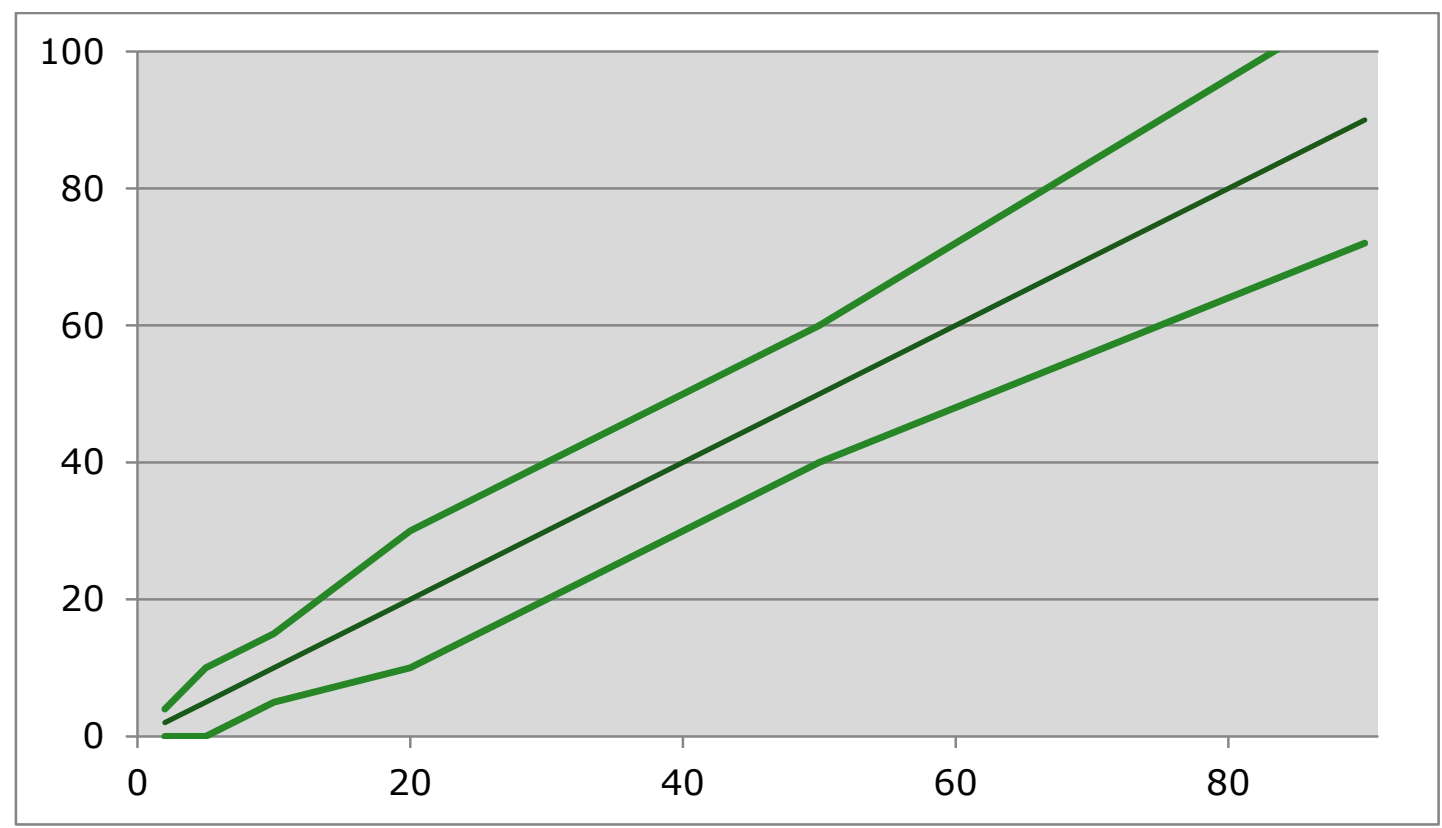

Figure 1 IAG model for estimating uncertainty. X-axis: correct portion of ingredient in \%, Y-axis: estimated portion of ingredient in \%. Inner line: correct estimation, outer lines: limits for uncertainty interval at a given percentage. 


\section{Results}

Twenty-seven samples were sent to all participants, for which 25 sets of results were returned. All results were received by $\mathrm{E}$-mail, in most cases by means of a scan and the original report file. Not in all cases a scan as pdf-file was submitted although this was clearly requested. In all those cases that a participant send in several versions of the report sheet the most recent version was used. All reports were included.

The 25 participants, which successfully submitted their results, originated from 10 countries: 9 member states of the European Union, and one other country. The list of participants is presented in Annex 5. More than half of the participants originated from Germany (13).

The procedure for the analysis of the composition is described in IAG method A2 (IAG, s.n.). This method is familiar to most participants as members of IAG section Microscopy. This method was applied by 16 participants. Other applied methods include a VD LUFA method, the AFNOR V18A method, an AAFM method, and internal laboratory procedures.

The results of the 25 participants are fully presented in Annex 6 and summarised in Table 2. The evaluations will be based on the pooled results per participants for the wheat products and for the corn products, since some participants did not discriminate between the specific types.

Table 2 Overview of the main ingredients of the analysed sample, the correct composition, the apriori calculated uncertainty range, and the statistics of the results in terms of median and numbers of participants that under- or overestimated the share of the ingredients. $N=25$.

\begin{tabular}{|c|c|c|c|c|c|}
\hline ingredient & correct & range: & median & \# $(\%)$ under est. & \# ( $\%)$ over est. \\
\hline Corn total & $30.0 \%$ & $20.0-40.0 \%$ & $22.0 \%$ & $11(44 \%)$ & $0(0 \%)$ \\
\hline Citrus pulp & $15.0 \%$ & $7.5-22.5 \%$ & $12.0 \%$ & $10(40 \%)$ & $3(12 \%)$ \\
\hline Beet pulp & $15.0 \%$ & $7.5-22.5 \%$ & $20.0 \%$ & $0(0 \%)$ & $8(32 \%)$ \\
\hline Wheat total & $10.0 \%$ & $5.0-15.0 \%$ & $13.0 \%$ & $0(0 \%)$ & $7(28 \%)$ \\
\hline Soy meal & $5.0 \%$ & $0.0-10.0 \%$ & $5.0 \%$ & NA & $1(4 \%)$ \\
\hline
\end{tabular}

The estimated amounts were correct in $71.4 \%$ of the estimations of the seven major ingredients as listed in Table 2. Three out of 25 participants made one error, seven participants made two errors, seven participants made three errors, two participants made four errors, and one participant made five errors. There is no clear correlation with the method applied.

The ingredient citrus pulp was underestimated or not found in $40 \%$ of the result sets. Related to this, beet pulp was in $32 \%$ of the cases overestimated. Figure 2 illustrates the distribution of the estimated shares of the seven major ingredients. At a real share of $15 \%$, citrus pulp, palmkernelmeal and beet pulp show large differences among their estimations. Above this, corn as major ingredient was underestimated in $44 \%$ of the reports. DDGS was reported by one participant, possibly as indication of the corn portion in the feed, but without further specification of that DDGS ingredient. One participant estimated the total of beet and citrus pulp at a share of $20 \%$. Since this would be the lower limit for a total share of $30 \%$ for both these ingredients, this was accepted as correct. In principle, underestimations cannot occur for ingredients with the lower limit of the range at $0.0 \%$.

The indications of the target animal for this type of feed included ruminant (10), cattle (8) and pig (1). Six participants did not provide an indication. Considering the choice to mimic a formulation of a ruminant feed, this result is near to optimal. 


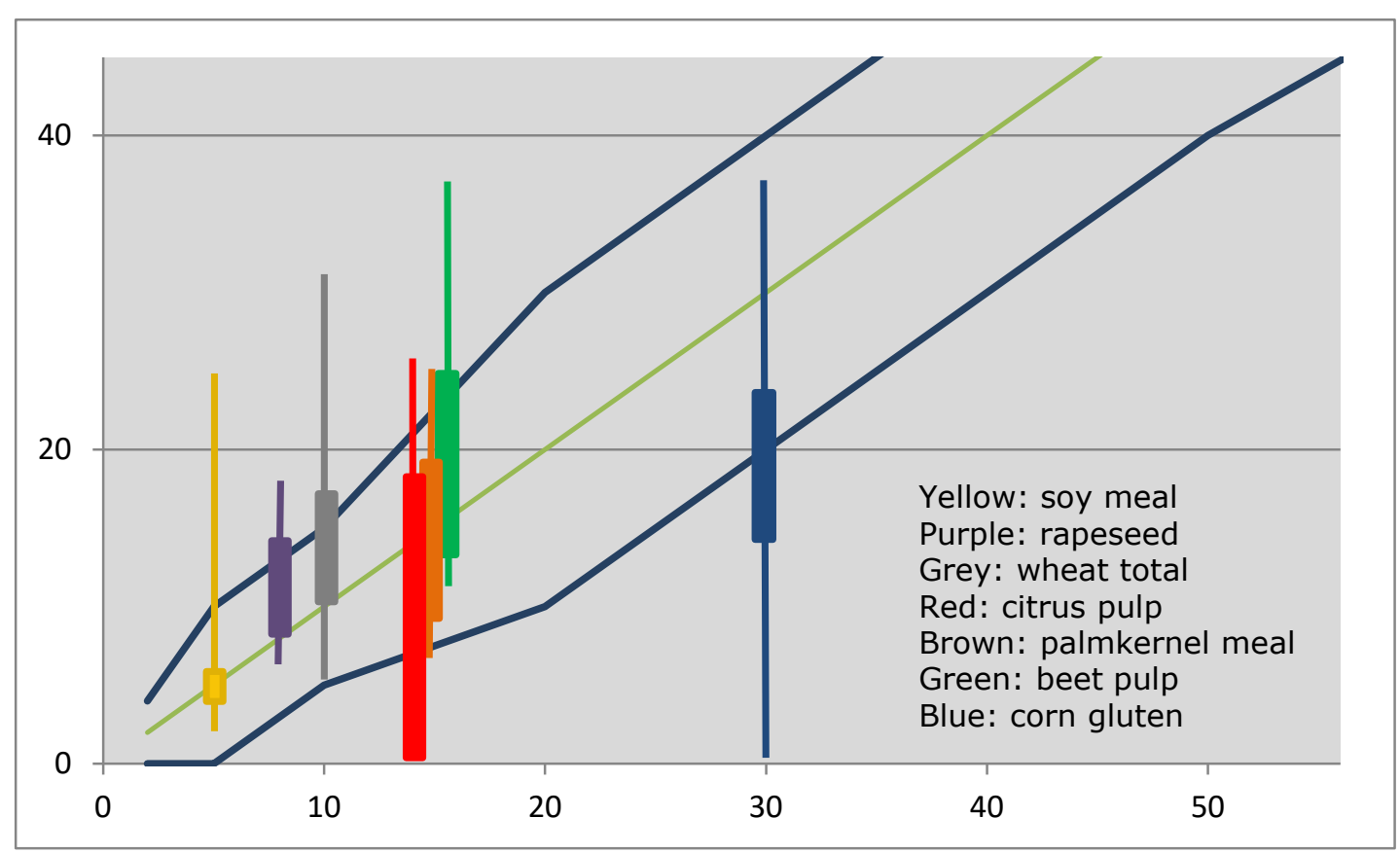

Figure 2 The results of the IAG ring test composition 2016 projected on the uncertainty limits of the IAG model. $X$-axis: real share, $Y$-axis: estimated share. Bars: $P_{25}-P_{75}$ percentile interval, vertical line: minimum - maximum range. 


\section{Discussion}

\subsection{Method application}

Several aspects are involved in the process of identification. Examinations at different magnifications are important in a specific order and additional evaluation steps are applied depending on the initial results. Specific expertise is needed depending on the type of ingredients, e.g. starch identification for cereal products and tuber crops, and structure of fibres and oil detection for by-products of oilseeds. Notwithstanding this complicated procedure and compared to the established limits (Figure 2) the current results need further attention, since the number of under- and over-estimations was lower in previous years (2014: 7.7\%, 2015: 20.4\%, 2016: 28.6\%; van Raamsdonk et al., 2014, 2015, this report). This comparison is affected by a bias: the 2014 test set up differently, aiming at label control, i.e. a declaration was given, which means that a direction towards the composition was given. The tests of last year and this year were blank, without any indication of a composition.

A major cause of the number of under- and over-estimations was the combination of beetpulp and citruspulp. These two ingredients can usually be discriminated based on their features, since one is a tuber (beet) and the other is a fruit (citrus). In contrast to last year and despite the apparent difficulty to identify and estimate the share of certain ingredients, the indications of the target animal were very consistent: 18 out of 25 participants indicated ruminant or cattle as targeted animal. This might be based on the high share of the pulp ingredients.

Results of IAG ring tests on composition of compound feeds in previous years (unpublished results) revealed a trend in the sense that higher shares are underestimated and lower shares are overestimated. The IAG model for uncertainty limits was agreed upon in 2006 after an extensive evaluation of alternatives. Nevertheless, in the range of $5-10 \%$ share of an ingredient in the formulation of a feed (Table 1) absolute limits were used in the model. This is also the range where overestimations are to be expected. A further analysis of unpublished results of past IAG ring tests for composition could provide data for improving the model.

In the past assessment of the biological composition of a feed was supported and, if necessary, adjusted by proximate analysis, of which Weende analysis is the classical approach (German: Weender Analyse; https://de.wikipedia.org/wiki/Futtermittelanalytik). Weende analysis, originally developed in the $19^{\text {th }}$ century (Henneberg and Stohmann, 1859) provides information on basic chemical parameters: moisture, contents of ash, fat, protein and crude fibres. Since extensive information is available on the parameters of individual ingredients, the initial visually estimated shares of the several biological ingredients can be confirmed or optimized using this detail data. Currently several approaches exist for proximate analysis, such as Cornell Net Carbohydrate and Protein System (CNCPS), Van Soest and Near-Infrared Reflectance Spectroscopy, although these systems do not aim at the same set of parameters (Bovera et al., 2003; Godoy et al., 2016). It needs to be stated that the sole visual analysis of the composition of a compound feed without complementary information lacks the possibility of confirmation and adjustment, which might influence the precision of the final result. A good process description consisting of necessary steps, sieve fractions, the necessary parameters to be established in every step and for every fraction, and the procedure for combining all data in a final conclusion, together with documentation on identifying feed ingredients could help to improve the method.

\subsection{Justification for establishing composition}

European legislation requires that feeds and feed materials are labelled according to a range of requirements, including composition. It has been stated that labelling serves enforcement, traceability and control purposes (Regulation (EC) 767/2009, pre-ambule 17). Feed materials should be mentioned in order of decreasing share, and additional information on composition should be available on request with uncertainty limits of $+/-15 \%$ (Regulation (EC) 767/2009, Article 17). It is not stated if this is a relative or absolute range. Annex IV of Regulation (EC) 767/2009 presents requirements for 
the labelling of basic parameters such as crude proteins, crude fibres, sugars, starch, oils and fats, minerals, moisture, crude ash and related parameters with a mix of absolute and relative ranges.

Monitoring of the correct declaration of the amount of the feed materials used in a compound feed (or other feed) is necessary for two reasons.

At first economic fraud can be based on the replacement of an expensive ingredient by a cheaper one. Secondly, certain compositions can give direction to look for specific unwanted contaminants. The fractionation of a sample in a sediment and a flotate can help to pinpoint the presence of contaminants and might improve their traceability. In the framework of the current report these opportunities apply to feed analysis. In a broader view, composition analysis in the entire food chain can improve the effect of monitoring actions. The new legislation on food labelling (Regulation (EC) $1169 / 2011$ ), effective from December $13^{\text {th }} 2014$, obliges to provide more detailed information to customers on composition and related topics. 


\section{General conclusions and recommendations}

\section{$5.1 \quad$ Conclusions}

The current results indicate that specific formulations can influence the precision of the estimation of the composition of the feed. The estimations for some ingredients can be mutually influencing, such as for beet pulp and citrus pulp. Corn was underestimated by almost half of the participants. Still almost three quarter of all estimations appeared to be correct in the ranges of the uncertainty model. This means that visual inspection of the composition of a sample can be used for label control and this method can support traceability of ingredients in case of an incidence.

The current lack of a complementary system for (chemical) proximate analysis could be a drawback for the overall approach of supporting traceability, necessary for fighting food fraud and for supporting feed safety. Besides a proper method description and up-to-date descriptions of ingredients, well developed skills of technicians are vital for a good performance.

\subsection{Recommendations}

- A more detailed process description could help to optimise the method for establishing the composition of a compound feed.

- In the view of the need for proper means for identification, tools for maintenance and dissemination of expertise are important for future performance.

- Considering the general overestimation, especially at lower shares, an evaluation of the IAG uncertainty model can help to improve its application. 


\section{Acknowledgements}

The board of IAG section Feeding Stuff Microscopy (dr. I. Paradies-Severin (LUFA, Hameln), dr. G. Frick (ALP, Posieux) and ir. J. Vancutsem (FAVV, Tervuren), dr. R. Weiss (AGES, Vienna)) supported this study as advisory board for communication with the scientists and laboratories working in this research field, and in the final report activities. Their contributions are greatly acknowledged. 


\section{References}

Bovera, F., M. Spanghero, G. Galassi, F. Masoero, A. Buccioni, 2003. Repeatability and reproducibility of the Cornell Net carbohydrate and Protein System analytical determinations. Ital. J. Anim. Sci. 2: 41-50.

European Commission, 2010. Commission Regulation (EU) No 242/2010 of 19 March 2010 creating the Catalogue of feed materials. OJ L 77, 24.3.2010, p. 17-32.

European Union, 2009. Regulation (EC) No 767/2009 of the European Parliament and of the Council of 13 July 2009 on the placing on the market and use of feed, amending European Parliament and Council Regulation (EC) No 1831/2003 and repealing Council Directive 79/373/EEC, Commission Directive 80/511/EEC, Council Directives 82/471/EEC, 83/228/EEC, 93/74/EEC, 93/113/EC and 96/25/EC and Commission Decision 2004/217/EC. OJ L 229, 1.9.2009, p. 1-28.

European Union, 2011. Regulation (EU) No 1169/2011 of the European Parliament and of the Council of 25 October 2011 on the provision of food information to consumers, amending Regulations (EC) No 1924/2006 and (EC) No 1925/2006 of the European Parliament and of the Council, and repealing Commission Directive 87/250/EEC, Council Directive 90/496/EEC, Commission Directive 1999/10/EC, Directive 2000/13/EC of the European Parliament and of the Council, Commission Directives 2002/67/EC and 2008/5/EC and Commission Regulation (EC) No 608/2004. OJ L 304, 22.11.2011, p. 18-63.

Godoy, M.R.C. de, M. Hervera, K.S. Swanson and G.C. Fahey Jr., 2016. Innovations in Canine and Feline Nutrition: Technologies for Food and Nutrition Assessment. Annu. Rev. Anim. Biosci. 4: 311-333.

Henneberg, W., Stohmann, F., 1859. Ueber das erhaltungsfutter volljaehrigen rindviehs. J. Landwirtsch. 3: 485-551.

IAG, s.n. Method for the Identification and Estimation of Constituents in Animal Feedingstuff. IAGMethod A2. http://www.iag-micro.org/files/iag-a2_identification_estimation.pdf.

Raamsdonk, L.W.D. van, V.G.Z. Pinckaers, J.J.M. Vliege, 2014. IAG ring test feed composition 2014. Report 2014.010. RIKILT, Wageningen, pp. 23.

Raamsdonk, L.W.D. van, N. van de Rhee, V.G.Z. Pinckaers, J.J.M. Vliege, 2015. IAG ring test feed composition 2015. Report 2015.017. RIKILT, Wageningen, pp. 26.

Raamsdonk, L.W.D. van, N. van de Rhee, I.M.J. Scholtens, T.W. Prins, J.J.M. Vliege, V.G.Z. Pinckaers, 2016. IAG ring test animal proteins 2016. Report 2016.\#\#\#. RIKILT, Wageningen, pp. 32. 


\section{Annex 1 Basic instructions for the test procedure}

\section{IAG ring test 2016 composition}

Instructions for the IAG ring test

1 You have received a box with an introduction letter and either one or four vials containing 50 grams of possibly contaminated animal feed. Please report the receipt of your package as soon as possible by E-mail to the address mentioned below.

The sample meant for analysis of composition is indicated on the letter enclosed in the package. Analysis for composition is preferably carried out using method A2 of the IAG section Microscopy. Other methods, however, are allowed. Take care to homogenise the content of each vial before taking the amount for analysis.

The sample meant for analysis of composition is also part of the sample set for the detection of animal proteins. The amount of material ( 50 grams) should be available for performing both tests.

\section{Link to IAG method A2}

The results need to be reported as percentual estimations on the tab "Results". The organiser will apply the uncertainty intervals to your estimations as part of the evaluation. Reporting consists of the following steps:

Please fill in the questionnaire on the page "Procedure".

Most of the cells contain a drop-down list. These lists can be used to select an answer as follows. When clicking on a cell, the cursor changes into a hand. A second click will open the drop-down list.

Your unique lab number is mentioned in the introduction letter.

All the fields with a drop-down list have to be completed.

Please enter your results in the fields at page "Results". Your unique lab number automatically shows up after your have entered it at the page Procedure. Enter yourself the unique label of the vial. organisers in two ways:

Save the Excel file by using "Save as ...", add your unique lab code to the end of name (replace the \#\# signs with your lab number). The forms have to be sent by E-mail as Excel file and as a scan (*.PDF) to leo.vanraamsdonk@wur.nl and to nastasja.vanderhee@wur.nl.

Results will be included in the final evaluation and report only if both forms are sent in by electronic mail, and after the proper receipt of the requested fee. 


\section{Annex 2 Report form for procedure details}

\begin{tabular}{|c|c|c|}
\hline $\begin{array}{l}\text { Please complete at least all the } \\
\text { pink cells with a drop down list } \\
\text { that apply to your procedure }\end{array}$ & $\begin{array}{l}\text { select your choice from a drop } \\
\text { down list }\end{array}$ & $\begin{array}{l}\text { type in your answer if } \\
\text { necessary }\end{array}$ \\
\hline \multicolumn{3}{|l|}{ IAG ring test 2014 composition } \\
\hline Please select your unique lab number & -- select -- & \\
\hline $\begin{array}{l}\text { Have you read the ring test } \\
\text { instructions? }\end{array}$ & -- select -- & \\
\hline Which detection method do you use? & -- select -- & \\
\hline & & \\
\hline
\end{tabular}




\section{Annex 3 Report form results}

Please complete the necessary pink cells

for showing your composition of the

ingredients; add your sample number,

the sediment amount and the final

conclusion on feed type.

IAG ring test 2015 composition

lab number

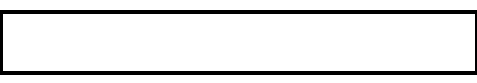

sample number

estimated \%

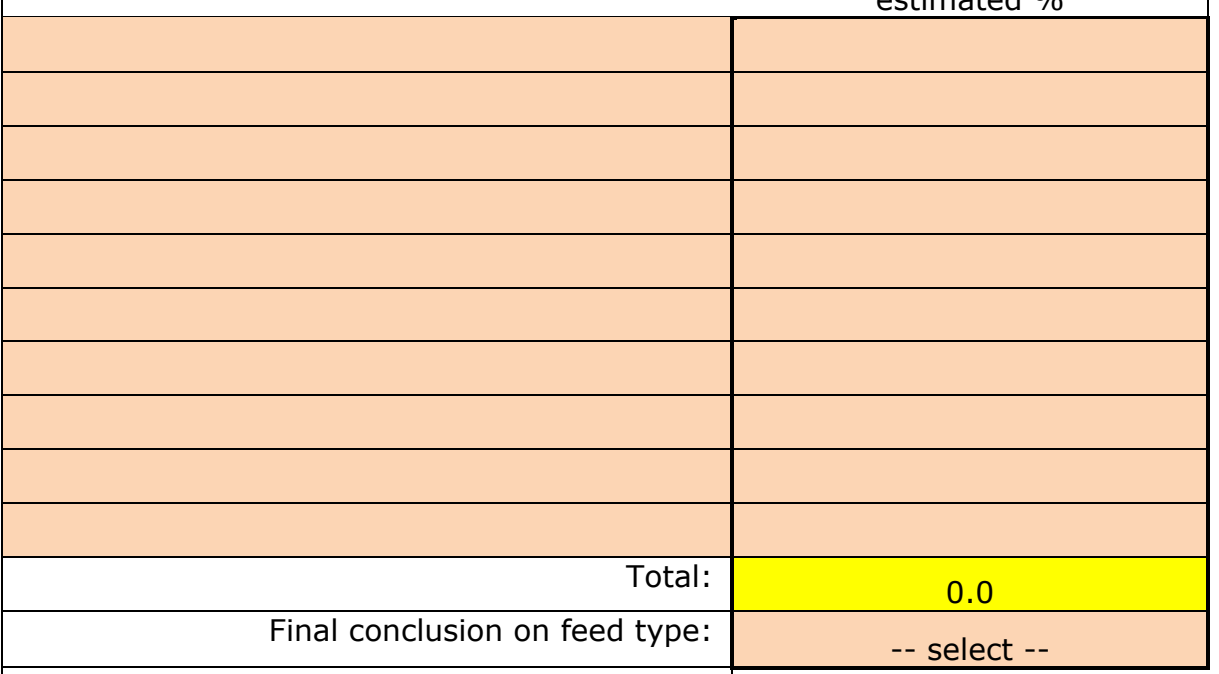

Comment if necessary

Signature:

Date: 


\section{Annex 4 Additional instructions}

Test 2015-B: botanic composition of sample: [

]

The sample with the number indicated here $\uparrow$ is meant for the analysis of the botanic composition. Take care to homogenise the content of the vial before taking the amount for analysis. This sample will be used for two purposes: detection of animal proteins if you have subscribed to this ring test, and analysis of botanic composition.

The current test does not provide a label declaration. The report form contains a series of empty rows where the ingredients can be entered in order of their share (highest share on top), together with your estimation of the share in percent in the second column. Finally you are requested to indicate the assumed target of the feed (e.g. broiler feed, calve feed).

All results can be entered in the report form with "composition" in the name. 


\section{Annex 5 List of participants}

\begin{tabular}{|c|c|}
\hline Austrian Agency for Health and Food Safety-AGES & Austria \\
\hline FLVVT & Belgium \\
\hline Danish Veterinary and Food Administration & Denmark \\
\hline IPL Atlantique & France \\
\hline Inovalys-Nantes & France \\
\hline CVUA-RRW & Germany \\
\hline SGS Germany GmbH & Germany \\
\hline Landeslabor Berlin-Brandenburg & Germany \\
\hline LUFA Nord-West & Germany \\
\hline BWZ der BFV & Germany \\
\hline Futtermittelinstitut Stade (LAVES) & Germany \\
\hline Veravis $\mathrm{GmbH}$ & Germany \\
\hline LTZ Augustenberg & Germany \\
\hline LUFA-Speyer & Germany \\
\hline Bayerisches Landesamt fur Gesundheit und Lebensmittelsicherheit & Germany \\
\hline Universität Hohenheim, LA Chemie (710) & Germany \\
\hline $\begin{array}{l}\text { Staatliche Betriebsgesellschaft für Umwelt und Landwirtschaft, GB6-Labore } \\
\text { Landwirtschaft / LUFA, FB62 }\end{array}$ & Germany \\
\hline Thüringer Landesanstalt für Landwirtschaft Jena & Germany \\
\hline MIPAAF - ICQRF - LABORATORIO DI MODENA & Italy \\
\hline Nutreco Nederland BV - Masterlab & Netherlands \\
\hline Nutrilab BV & Netherlands \\
\hline Cargill Poland & Poland \\
\hline Instytut Zootechniki PIB, Pracownia w Szczecinie & Poland \\
\hline Trouw nutrition Espana & Spain \\
\hline Agroscope (ALP), Swiss Research Station & Switzerland \\
\hline
\end{tabular}




\section{Annex 6 Results}

\begin{tabular}{|c|c|c|c|c|c|c|c|c|c|c|}
\hline Ingredient & correct & range: & lab: & 1 & 2 & 3 & 4 & 8 & 9 & 10 \\
\hline corn gluten & & & & $36.0 \%$ & $40.0 \%$ & $22.0 \%$ & $10.0 \%$ & $15.3 \%$ & $1.5 \%$ & \\
\hline corn & & & & & & & & $3.9 \%$ & $22.0 \%$ & $22.5 \%$ \\
\hline corn total & $30.0 \%$ & $20.0-$ & $40.0 \%$ & $36.0 \%$ & $40.0 \%$ & $22.0 \%$ & $10.0 \%$ & $19.2 \%$ & $23.5 \%$ & $22.5 \%$ \\
\hline beet pulp & $15.0 \%$ & $7.5-$ & $22.5 \%$ & $12.0 \%$ & $25.0 \%$ & $12.0 \%$ & $27.0 \%$ & $19.6 \%$ & $37.0 \%$ & $27.5 \%$ \\
\hline citrus pulp & $15.0 \%$ & $7.5-$ & $22.5 \%$ & $16.0 \%$ & & $12.0 \%$ & $15.0 \%$ & $23.4 \%$ & & $3.0 \%$ \\
\hline \multicolumn{11}{|l|}{ beet and citrus pulp } \\
\hline Palmkernelmeal & $15.0 \%$ & $7.5-$ & $22.5 \%$ & $16.0 \%$ & $9.0 \%$ & $14.0 \%$ & $12.0 \%$ & $8.6 \%$ & $10.0 \%$ & $7.5 \%$ \\
\hline rapeseed meal & $8.5 \%$ & $3.5-$ & $13.5 \%$ & $6.5 \%$ & $9.0 \%$ & $18.0 \%$ & $10.0 \%$ & $9.5 \%$ & $17.0 \%$ & $12.5 \%$ \\
\hline Wheat & $5.0 \%$ & $0.0-$ & $10.0 \%$ & & $3.0 \%$ & & & $8.9 \%$ & & \\
\hline wheat semolina (and bran) & $5.0 \%$ & $0.0-$ & $10.0 \%$ & & $5.0 \%$ & & & $6.9 \%$ & & \\
\hline wheat products & $10.0 \%$ & $5.0-$ & $15.0 \%$ & $7.0 \%$ & & $16.0 \%$ & $18.0 \%$ & & $9.0 \%$ & $12.5 \%$ \\
\hline soy meal & $5.0 \%$ & $0.0-$ & $10.0 \%$ & $4.0 \%$ & $5.0 \%$ & $2.0 \%$ & $5.0 \%$ & $2.7 \%$ & $2.0 \%$ & $7.5 \%$ \\
\hline Minerals & $1.5 \%$ & $0.0-$ & $3.0 \%$ & $2.5 \%$ & & $4.0 \%$ & $3.0 \%$ & $1.2 \%$ & $1.5 \%$ & $3.0 \%$ \\
\hline fat and minerals & & & & & $4.0 \%$ & & & & & \\
\hline \multicolumn{11}{|l|}{ DDGS } \\
\hline potato pulp & & & & & & & & & & $3.0 \%$ \\
\hline \multicolumn{11}{|l|}{ barley } \\
\hline rye & & & & & & & & & & $1.0 \%$ \\
\hline \multicolumn{11}{|l|}{ sunflower } \\
\hline \multicolumn{11}{|l|}{ Other } \\
\hline Total & $100 \%$ & & & $100 \%$ & $100 \%$ & $100 \%$ & $100 \%$ & $100 \%$ & $100 \%$ & $100 \%$ \\
\hline Final conclusion on feed type & & & & cattle & ruminant & cattle & ruminant & cattle & & cattle \\
\hline
\end{tabular}

\begin{tabular}{|c|c|c|c|c|c|c|c|c|c|c|}
\hline ingredient & correct & |range: & lab: & 11 & 13 & 14 & 17 & 21 & 22 & 23 \\
\hline corn gluten & & & & & $25.0 \%$ & $17.0 \%$ & & $25.0 \%$ & & $17.0 \%$ \\
\hline corn & & & & $37.0 \%$ & & & $23.0 \%$ & & & \\
\hline corn total & $30.0 \%$ & $20.0-$ & $40.0 \%$ & $37.0 \%$ & $25.0 \%$ & $17.0 \%$ & $23.0 \%$ & $25.0 \%$ & $14.0 \%$ & $17.0 \%$ \\
\hline beet pulp & $15.0 \%$ & $7.5-$ & $22.5 \%$ & $11.0 \%$ & $27.0 \%$ & $12.0 \%$ & $20.0 \%$ & $16.0 \%$ & $20.0 \%$ & $20.0 \%$ \\
\hline citrus pulp & $15.0 \%$ & $7.5-$ & $22.5 \%$ & & & & $13.0 \%$ & & & $19.0 \%$ \\
\hline \multicolumn{11}{|l|}{ beet and citrus pulp } \\
\hline palmkernelmeal & $15.0 \%$ & 7.5- & $22.5 \%$ & $19.0 \%$ & $20.0 \%$ & $18.0 \%$ & $20.0 \%$ & $25.0 \%$ & $14.0 \%$ & $12.0 \%$ \\
\hline rapeseed meal & $8.5 \%$ & $3.5-$ & $13.5 \%$ & $9.0 \%$ & $10.0 \%$ & $14.0 \%$ & $6.5 \%$ & $16.0 \%$ & $15.0 \%$ & $9.0 \%$ \\
\hline wheat & $5.0 \%$ & $0.0-$ & $10.0 \%$ & & & & $4.5 \%$ & $5.0 \%$ & & \\
\hline wheat semolina (and bran) & $5.0 \%$ & $0.0-$ & $10.0 \%$ & & $10.0 \%$ & & & $6.0 \%$ & & \\
\hline wheat products & $10.0 \%$ & $5.0-$ & $15.0 \%$ & $17.0 \%$ & & $31.0 \%$ & $6.5 \%$ & & $17.0 \%$ & $15.0 \%$ \\
\hline soy meal & $5.0 \%$ & $0.0-$ & $10.0 \%$ & $5.0 \%$ & $4.0 \%$ & $4.0 \%$ & $4.5 \%$ & $5.0 \%$ & $9.0 \%$ & $6.0 \%$ \\
\hline minerals & $1.5 \%$ & $0.0-$ & $3.0 \%$ & $2.0 \%$ & $2.5 \%$ & $2.0 \%$ & $2.0 \%$ & $2.0 \%$ & & $2.0 \%$ \\
\hline \multicolumn{11}{|l|}{ fat and minerals } \\
\hline \multicolumn{11}{|l|}{ DDGS } \\
\hline \multicolumn{11}{|l|}{ potato pulp } \\
\hline \multicolumn{11}{|l|}{ barley } \\
\hline \multicolumn{11}{|l|}{ rye } \\
\hline \multicolumn{11}{|l|}{ sunflower } \\
\hline Other & & & & & $1.5 \%$ & $2.0 \%$ & & & $11.0 \%$ & \\
\hline Total & $100 \%$ & & & $100 \%$ & $100 \%$ & $100 \%$ & $100 \%$ & $100 \%$ & $100 \%$ & $100 \%$ \\
\hline Final conclusion on feed type & & & & ruminant & ruminant & cattle & & & ruminant & cattle \\
\hline
\end{tabular}




\begin{tabular}{|c|c|c|c|c|c|c|c|c|c|}
\hline Ingredient & correct & range: & lab: & 24 & 27 & 28 & 30 & 32 & 41 \\
\hline corn gluten & & & & $17.0 \%$ & & & $11.2 \%$ & $15.0 \%$ & \\
\hline corn & & & & & $5.0 \%$ & $23.0 \%$ & & & \\
\hline corn total & $30.0 \%$ & $20.0-$ & $40.0 \%$ & $17.0 \%$ & $5.0 \%$ & $23.0 \%$ & $11.2 \%$ & $15.0 \%$ & $23.0 \%$ \\
\hline beet pulp & $15.0 \%$ & $7.5-$ & $22.5 \%$ & $24.6 \%$ & $32.0 \%$ & $15.0 \%$ & $24.2 \%$ & $20.0 \%$ & $13.0 \%$ \\
\hline citrus pulp & $15.0 \%$ & $7.5-$ & $22.5 \%$ & $17.5 \%$ & & $13.0 \%$ & $22.4 \%$ & $25.0 \%$ & $9.0 \%$ \\
\hline \multicolumn{10}{|l|}{ beet and citrus pulp } \\
\hline Palmkernelmeal & $15.0 \%$ & $7.5-$ & $22.5 \%$ & $15.0 \%$ & $15.0 \%$ & $16.0 \%$ & $15.4 \%$ & $10.0 \%$ & $20.0 \%$ \\
\hline rapeseed meal & $8.5 \%$ & $3.5-$ & $13.5 \%$ & $6.0 \%$ & $10.0 \%$ & $12.0 \%$ & $9.1 \%$ & $7.0 \%$ & $14.0 \%$ \\
\hline Wheat & $5.0 \%$ & $0.0-$ & $10.0 \%$ & & & & & & \\
\hline wheat semolina (and bran) & $5.0 \%$ & $0.0-$ & $10.0 \%$ & $10.0 \%$ & $5.0 \%$ & & & & $0.2 \%$ \\
\hline wheat products & $10.0 \%$ & $5.0-$ & $15.0 \%$ & & $4.0 \%$ & $13.0 \%$ & $10.0 \%$ & $18.0 \%$ & $15.0 \%$ \\
\hline soy meal & $5.0 \%$ & $0.0-$ & $10.0 \%$ & $7.5 \%$ & $5.0 \%$ & $6.0 \%$ & $5.2 \%$ & $4.0 \%$ & $5.0 \%$ \\
\hline Minerals & $1.5 \%$ & $0.0-$ & $3.0 \%$ & $2.4 \%$ & $0.5 \%$ & $2.0 \%$ & $2.3 \%$ & $1.0 \%$ & $0.2 \%$ \\
\hline \multicolumn{10}{|l|}{ fat and minerals } \\
\hline DDGS & & & & & $22.0 \%$ & & & & \\
\hline \multicolumn{10}{|l|}{ potato pulp } \\
\hline \multicolumn{10}{|l|}{ barley } \\
\hline \multicolumn{10}{|l|}{ rye } \\
\hline \multicolumn{10}{|l|}{ sunflower } \\
\hline Other & & & & & $1.0 \%$ & & & & \\
\hline Total & $100 \%$ & & & $100 \%$ & $100 \%$ & $100 \%$ & $100 \%$ & $100 \%$ & $99 \%$ \\
\hline Final conclusion on feed type & & & & cattle & ruminant & cattle & ruminant & ruminant & \\
\hline
\end{tabular}

\begin{tabular}{|c|c|c|c|c|c|c|c|c|}
\hline ingredient & correct & range: & lab: & 42 & 43 & 44 & 48 & 51 \\
\hline corn gluten & & & & $20.0 \%$ & $18.0 \%$ & & & $15.5 \%$ \\
\hline corn & & & & & $6.0 \%$ & $25.0 \%$ & & \\
\hline corn total & $30.0 \%$ & $20.0-$ & $40.0 \%$ & $20.0 \%$ & $24.0 \%$ & $25.0 \%$ & $0.0 \%$ & $15.5 \%$ \\
\hline beet pulp & $15.0 \%$ & $7.5-$ & $22.5 \%$ & & $21.0 \%$ & $15.0 \%$ & $15.0 \%$ & $21.5 \%$ \\
\hline citrus pulp & $15.0 \%$ & $7.5-$ & $22.5 \%$ & & $18.0 \%$ & $15.0 \%$ & & $25.7 \%$ \\
\hline beet and citrus pulp & & & & $20.0 \%$ & & & & \\
\hline palmkernelmeal & $15.0 \%$ & $7.5-$ & $22.5 \%$ & $20.0 \%$ & $9.0 \%$ & $15.0 \%$ & & $6.4 \%$ \\
\hline rapeseed meal & $8.5 \%$ & $3.5-$ & $13.5 \%$ & $8.0 \%$ & $8.0 \%$ & $10.0 \%$ & $15.0 \%$ & $8.3 \%$ \\
\hline wheat & $5.0 \%$ & $0.0-$ & $10.0 \%$ & & & & & \\
\hline wheat semolina (and bran) & $5.0 \%$ & $0.0-$ & $10.0 \%$ & $5.0 \%$ & $4.0 \%$ & & & $6.8 \%$ \\
\hline wheat products & $10.0 \%$ & $5.0-$ & $15.0 \%$ & & $10.0 \%$ & $10.0 \%$ & $30.0 \%$ & $7.3 \%$ \\
\hline soy meal & $5.0 \%$ & $0.0-$ & $10.0 \%$ & $25.0 \%$ & $4.0 \%$ & $7.5 \%$ & & $4.2 \%$ \\
\hline minerals & $1.5 \%$ & $0.0-$ & $3.0 \%$ & $2.5 \%$ & $2.0 \%$ & $2.0 \%$ & & $2.6 \%$ \\
\hline fat and minerals & & & & & & & & \\
\hline DDGS & & & & & & & & \\
\hline potato pulp & & & & & & $0.5 \%$ & & \\
\hline barley & & & & & & & $20.0 \%$ & \\
\hline rye & & & & & & & & \\
\hline sunflower & & & & & & & $5.0 \%$ & \\
\hline other & & & & & & & & \\
\hline total & $100 \%$ & & & $101 \%$ & $100 \%$ & $100 \%$ & $85 \%$ & $98 \%$ \\
\hline Final conclusion on feed type & & & & & ruminant & ruminant & pig & \\
\hline
\end{tabular}


RIKILT Wageningen University \& Research P.O. Box 230

6700 AE Wageningen

The Netherlands

$\mathrm{T}+31(0) 317480256$

www.wur.eu/rikilt

RIKILT report 2016.014
The mission of Wageningen University and Research is "To explore the potential of nature to improve the quality of life". Under the banner Wageningen University \& Research, Wageningen University and the specialised research institutes of the Wageningen Research Foundation have joined forces in contributing to finding solutions to important questions in the domain of healthy food and living environment. With its roughly 30 branches, 5,000 employees and 10,000 students, Wageningen University \& Research is one of the leading organisations in its domain. The unique Wageningen approach lies in its integrated approach to issues and the collaboration between different disciplines. 



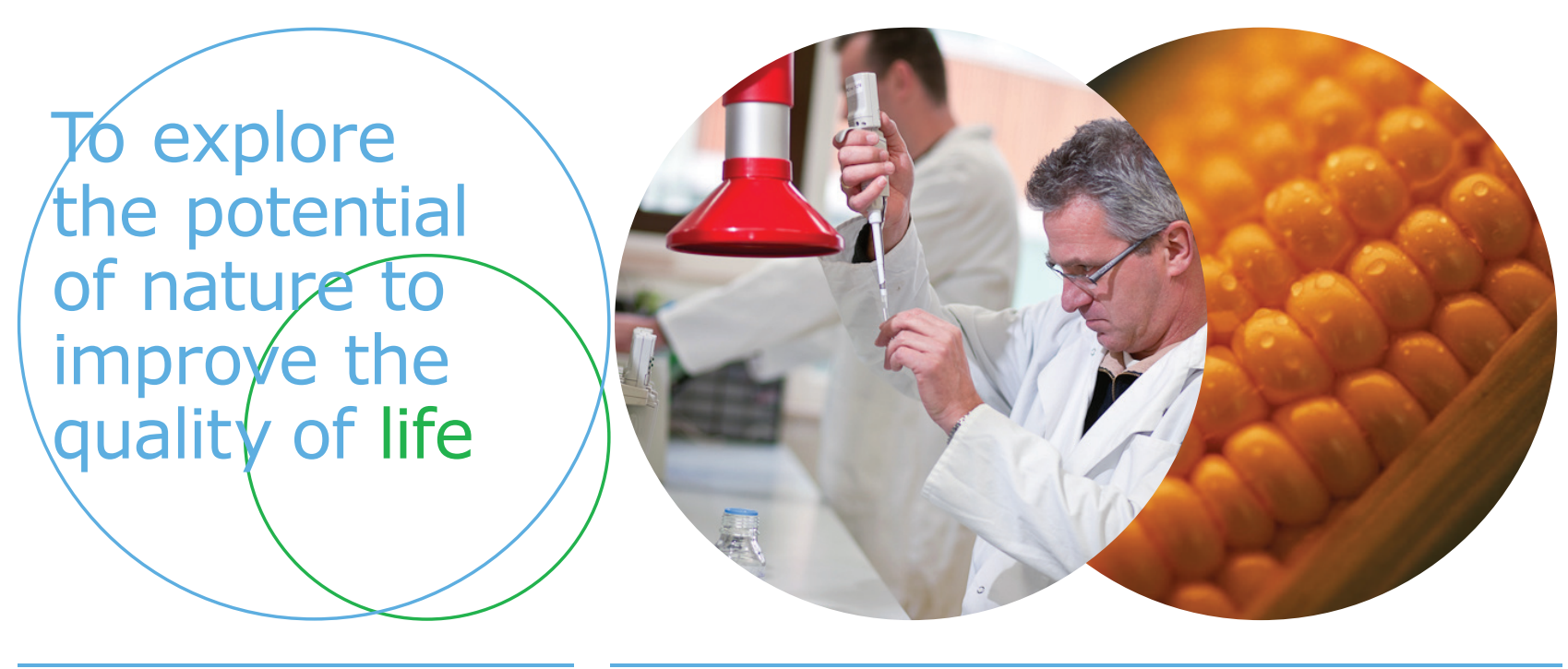

RIKILT Wageningen University \& Research P.O. Box 230

6700 AE Wageningen

The Netherlands

T +31 (0)317480256

www.wur.eu/rikilt

Report 2016.014
The mission of Wageningen University and Research is "To explore the potential of nature to improve the quality of life". Under the banner Wageningen University \& Research, Wageningen University and the specialised research institutes of the Wageningen Research Foundation have joined forces in contributing to inding solutions to important questions in the domain of healthy food and living environment. With its roughly 30 branches, 5,000 employees and 10,000 students, Wageningen University \& Research is one of the leading organisations in its domain. The unique Wageningen approach lies in its integrated approach to issues and the collaboration between different disciplines. 